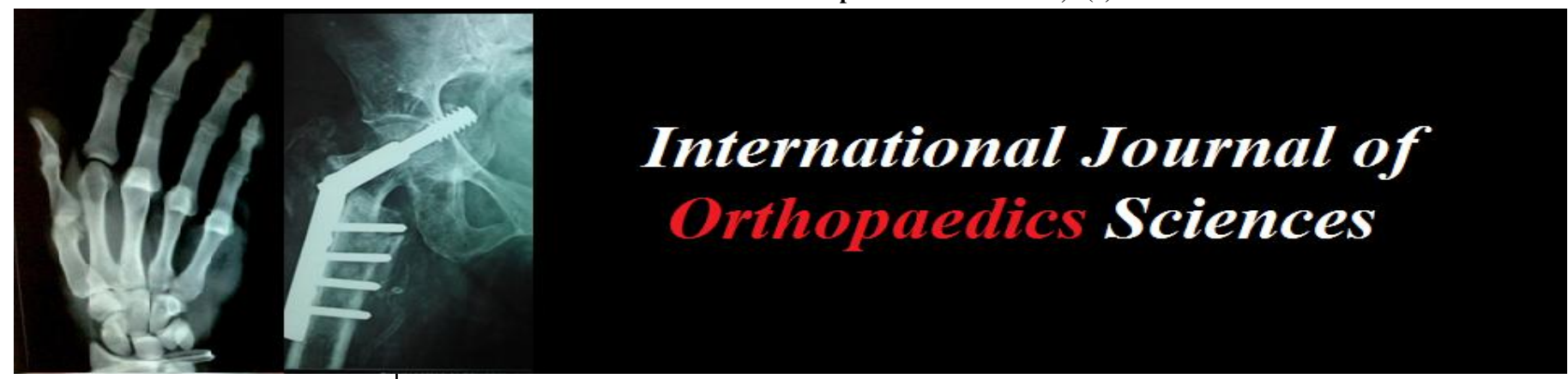

ISSN: $2395-1958$

IJOS 2018; 4(4): 474-477

(C) 2018 IJOS

www.orthopaper.com

Received: 23-08-2018

Accepted: 24-09-2018

Dr. Nakul S Shah

MS Orthopedics, DNB

Orthopedics MNAMS, Smt.

Kashibai Navale Medical College and Hospital, Narhe, Pune,

Maharashtra, India

Dr. Ashutosh A Ushir MBBS, Department of Orthopaedics, Smt. Kashiba

Navale Medical College and

Hospital, Narhe, Pune,

Maharashtra, India

Dr. Ashutosh A Ushir

DNB Orthopedics, Smt. Kashiba

Navale Medical College and

Hospital, Narhe, Pune,

Maharashtra, India
Correspondence

Dr. Ashutosh A Ushir

MBBS, Department of

Orthopaedics, Smt. Kashiba

Navale Medical College and

Hospital, Narhe, Pune,

Maharashtra, India

\section{Heterotopic ossification after total hip arthroplasty in Indian scenario: A radiographic retrospective study}

\author{
Dr. Nakul S Shah, Dr. Ashutosh A Ushir and Dr. Vijay Nemade
}

DOI: https://doi.org/10.22271/ortho.2018.v4.i4e.48

\section{Abstract}

Background: The study aims at providing Incidence rates with the use of posterior approach and the role of gender in development of HO after total hip arthroplasty in an Indian scenario.

Methods: 401 patients who had underwent total hip arthroplasty using posterior approach were studied retrospectively with the help of X-rays after a stipulated period of 12 weeks from the hospital database. The X-rays which were studied for any evidence of Hetertopic ossification and if present $\mathrm{HO}$ was classified using Brookers classification. The incidence rates were thus calculated along with incidence of each of the subtypes of $\mathrm{HO}$ with the use of posterior approach. The predisposition of sex for development of $\mathrm{HO}$ were noted.

Results: Evidence of HO was found in 32.9 percent of cases (132/401) with the incidence of type 1 $24.4 \%$ (98/401), type $2-6.4 \%$ (26/401), type 3 - 1.9\% (8/401), type 4- Nil.

The male to female ratio of total hip arthroplasty was found to be $65.08 \%$ percent $(261 / 401)$ males as compared to 34.92 percent females (140/401). Among males $35.63 \%(93 / 261)$ percent of patients developed $\mathrm{HO}$ and among females 27.85 percent (39/140) of patients developed HO. Also out of the 401 hips replaced 370 were uncemented THRs and 31 were cemented THRS. $36.67 \%$ (136/370) developed HO in uncemented implants and $29.03 \%(9 / 31)$ developed $\mathrm{HO}$ in cemented implants.

Conclusion: The study demonstrated an incidence of $32.9 \% \mathrm{HO}$ after primary THA in Indian population after using posterior approach with its incidence being higher in males.

Keywords: Heterotopic ossification, posterior approach, Indian scenario, total hip arthroplasty

\section{Introduction}

Heterotopic ossification (HO) is the formation of compact lamellar bone tissue outside the skeleton or more specifically in the soft tissues. Heterotrophic ossification after total hip arthroplasty is a recognised phenomenon with incidence ranging from 0.6 to $90 \%$ depending upon various studies the mean being $53 \%[1,2,3]$. But the incidence of symptomatic ossification is comparatively less ranging from $2 \%$ to $7 \%$ with only $1 \%$ requiring any surgical intervention $[4,5,6,7,8,9]$

Risk factors for heterotopic ossification include old age, gender $(\mathrm{M}>\mathrm{F}){ }^{[7]}$, a preexisting $\mathrm{HO}$ in contralateral hip or previous history of HO, ankylosing spondylitis, post traumatic arthritis, osteonecrosis and rheumatoid arthritis ${ }^{[10,11]}$. Risk factors related to surgical technique include the presence of haematoma, surgical dissection, approach used, amount of soft tissue damage, persistence of local debris in the form of cement, bone marrow bone dust ${ }^{[12]}$.

Majority of the studies available today are based on the western population and no consensus is available for the incidence of $\mathrm{HO}$ after hip arthroplasty in Indian patients. This study aims at providing these incidence rates with the effect of approach used, the role of gender in development of $\mathrm{HO}$ along with comparison of $\mathrm{HO}$ in cemented and uncemented implants.

\section{Material and Methods}

Collection and analysis of data was done at a tertiary care centre. All patients who had underwent total hip replacement for any of the standard indications, predominantly avascular necrosis of femoral head, rheumatoid arthritis and ankylosing spondylitis, during the time period of January 2013 to June 2016 were included in the study. All the surgeries were performed by specialised senior joint replacement surgeons using the posterior approach. 
The uncemented implants used were Smith and Nephew, Tennessee, Reflection and synergy-porus coated, Reflection and polar - HA coated. The cemented implants used were Exeter or CPCS plus cemented cups.

The study was retrospective in nature with serial $\mathrm{X}$-rays observed from the hospital database. The database used was Impacts bytes version1.2. Patients were included in the study on the basis of the presence in our computerised database of a minimum follow-up control at 12 weeks from the surgical intervention.

Data such as patients age at time of developing HO, sex of patient, and time at follow up along with the type of implantation (cemented or uncemented) were obtained from the database and the hospital records.

The exclusion criteria encompassed

1. Any previous surgery on the same hip.

2. Use of any other approach other than posterior approach.

3. Revision THRs

Database of 491 hips was found and the surgical approach used was posterior Southern Moore approach and no prophylactic measures were taken specifically to avoid heterotopic ossification. The X-rays which were done at subsequent follow ups were studied for any evidence of $\mathrm{HO}$ and were classified using the Brookers classification ${ }^{[13]}$.

Grade 1: The presence of isolated bone fragments of any size within periarticular soft tissue

Grade 2: The presence of bone spurs from the pelvis or femur with at least $1 \mathrm{~cm}$ between opposing bone surfaces

Grade 3: The presence of bone spurs reducing space between opposing bone surfaces to less than $1 \mathrm{~cm}$

Grade 4: Ossification with apparent ankylosis of the hip.

The incidence rates were thus calculated along with incidence of each of the subtypes of $\mathrm{HO}$ with the use of posterior approach. The predispositions of sex for development of $\mathrm{HO}$ were noted. Also the incidence of HO between cemented and uncemented implants were compared.

\section{Results}

A cohort of 491 patients was obtained from the database out of which 90 patients were lost to follow up. The main indication for total hip arthroplasty appeared to be avascular necrosis with other indications being hip arthritis, Rheumatoid arthritis, Ankylosing spondylitis, post traumatic arthritis, Perthes disease and developmental dysplasia of hip.

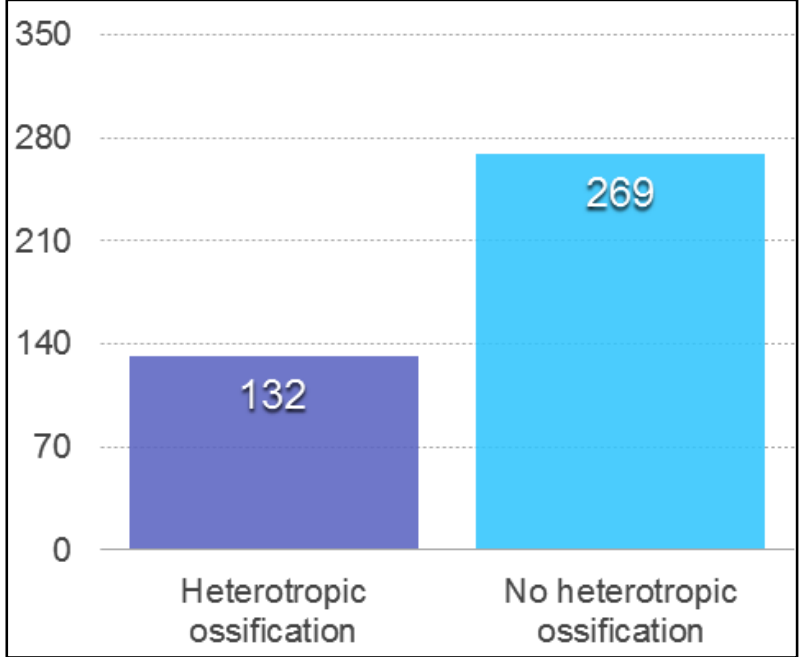

Out of the remaining 401 hips evidence of heterotopic ossification was found in $32.9 \%$ of cases (132/401) with the incidence of type $1-24.4 \%(98 / 401)$, type $2-6.4 \%$ (26/401), type $3-1.9 \%(8 / 401)$, type $4-$ No evidence of type $4 \mathrm{HO}$ was observed.

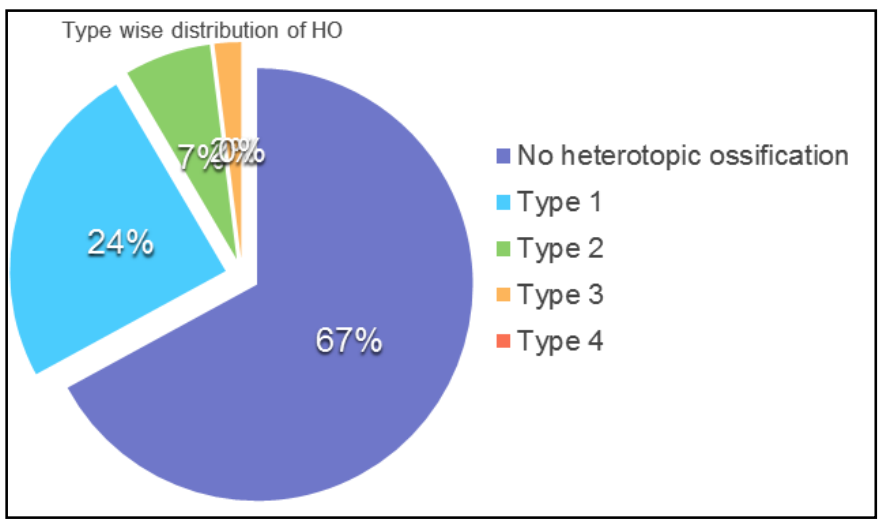

The mean follow up at which patients developed HO was observed to be 24 weeks.

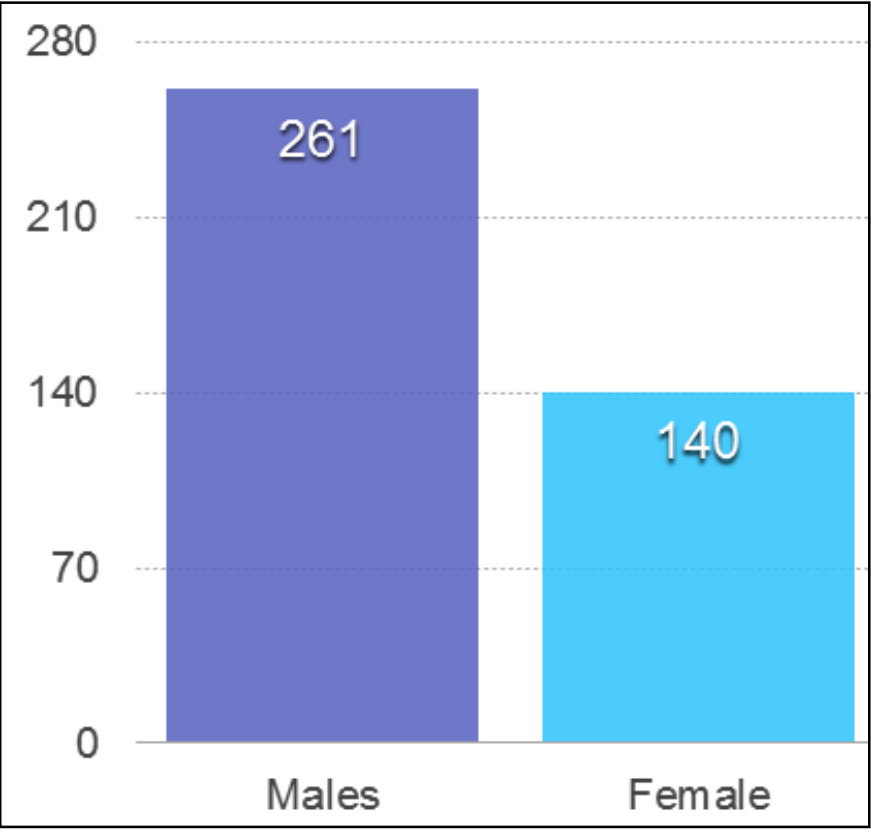

The male to female ratio who had undergone total hip arthroplasty was found to be $65.08 \%$ (261/401)males as compared to $34.92 \%$ females (140/401)(Refer Graph 2). Among males $35.63 \%(93 / 261)$ of patients developed HO and among females $27.85 \%$ (39/140) of patients developed HO (Refer Graph 4).

Also out of the 401 hips replaced 370 were uncemented THRs and 31 were cemented THRS. $36.67 \%$ (136/370) developed HO in uncemented implants and $29.03 \%$ (9/31) developed $\mathrm{HO}$ in cemented implants.

\section{Discussion}

Heterotopic ossification is a well-known phenomenon after total hip arthroplasty. It causes severe pain and reduces mobility of the patient leading to deterioration of functional outcome. Various clinical studies have shown the incidence of $\mathrm{HO}$ ranging from 0.6 to $90 \%{ }^{[4,5,6]}$. The causes of $\mathrm{HO}$ can be broadly divided into traumatic, genetic and neurological. HO following hip arthroplasty can be considered due to traumatic cause, due to damage to the soft tissues and wear and tear of 
the implant used. According to a study by Chalmers et al. the development of $\mathrm{HO}$ was due to the interplay between three essential factors: osteogenic precursor cell, inducing agents and a permissive environment [14]. The pluripotent mesenchymal cells in stromal tissue of bone marrow have osteogenic potential and have been termed as "Determined osteogenic precursor cells" (DOPC). These cells when released from medullary cavity and deposited into the periarticular tissues during the THA, may initiate heterotopic bone formation ${ }^{[15,16]}$. The stimulus for activation of the stem cells is considered to be the dimeneralized bone matrix which could induce bone formation with the help of BMP [17, 18]. Recently the role of Prostaglandin E2 is also considered in the development of HO $[19,20]$. This study reports retrospective data from a radiological cohort of 401 patients with an aim of providing incidence rates of heterotopic ossification in Indian population using the posterior approach, the gender predisposition for $\mathrm{HO}$ and the role of cemented and uncemented implants in development of HO.

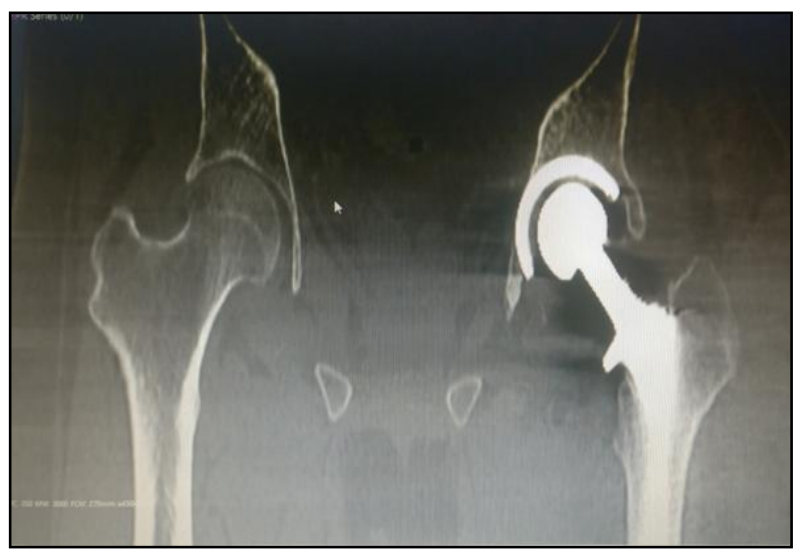

1 year post-operative CT scan showing type 2 Heterotopic ossification after total hip arthroplasty.

Of all the studied patients the incidence of heterotopic ossification was found to be $32.9 \%$ which is lesser as compared to the average incidence of $53 \%$ reported by several publications. ${ }^{[4,5,6,7,8,9]}$, this can be attributed to the approach used (posterior approach) which causes less traumatic dissection and soft tissue damage along with less handling of the gluteus medius muscle. Studies have reported the incidence rates of $\mathrm{HO}$ following anterior and anterolateral approaches to be significantly higher ranged at around $60 \%$, also various other studies point out towards lower incidence rates of $\mathrm{HO}$ in posterior approach. So we can safely conclude that posterior approach leads to lower incidence rates of $\mathrm{HO}$.
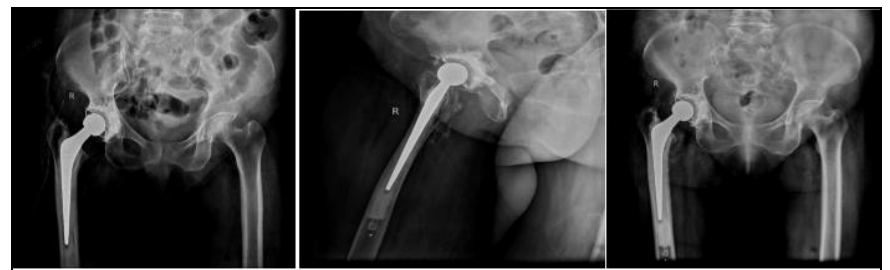

Xray images showing post-operative day 1(above left) and postoperative month 4 follow up (above middle and right) in a case of cemented hip prosthesis.

Also $35.63 \%$ of males and $27.85 \%$ of females developed periarticular $\mathrm{HO}$ which points towards higher incidence of $\mathrm{HO}$ in males as compared to females this is in agreement with literature the reasons for such findings should be investigated further ${ }^{[1,22]}$.
The findings of this study suggest comparatively higher inside of $\mathrm{HO}$ in uncemented implants as compared with that of cemented implants. Most of the implants used were HA coated implants so it was difficult to compare HO rates between the HA and porus coated implants.

Also a wide meta-analysis published in cochrane library hints at reduction in the incidence of heterotopic ossification by 54$64 \%$ with an adequate NSAID cover for 7- 14 days, if these results were applied to this study the incidence rates would have dropped down to 20 percent which is surely lesser than the mean incidence of $53 \%$ signifying that use of NSAIDs might decrease the risk of $\mathrm{HO}$.

Also the rate of $\mathrm{HO}$ which is 32.9 percent is still on the higher side which means that almost 1 in every 3 patient will develop HO. Based on literature review HO rates have been shown to decrease on use of preventive measures like radiation therapy and pharmacological prophylaxis with NSAIDs for a period of 10-14 days. Based on cochrane metaanalysis the incidence of $\mathrm{HO}$ reduces by 54 to $64 \%$ on use of prophylactic NSAIDs cover which would lead to the incidence to reduce to $16 \%$ in our study which is comparable with other studies signifying the fact that preventive measures should be undertaken to reduce $\mathrm{HO}$.

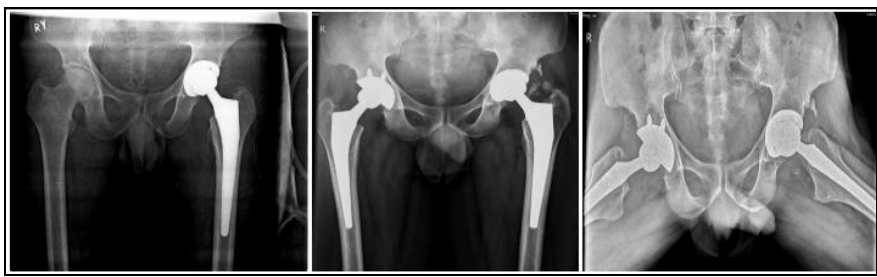

Type 3 Heteropic ossification in a 8 month follow up case of THA above left showing Post op day 1 image.

However the study has its limitations like the sample size used was smaller, and being a retrospective radiographic study we were not able to assess the functional outcomes associated with severe $\mathrm{HO}$ (type 3 , 4) and whether any surgical intervention was required for the same. Also the mean follow up was 12 weeks which might have underestimated the actual incidence of HO. Although HO can be observed on plain radiographs by 6 weeks it takes almost 6 months for its complete maturation which can lead to underestimation. Also the number of uncemented implants was much higher than the cemented ones so the comparison was not legit.

\section{Conclusion}

The study demonstrated an incidence of $32.9 \% \mathrm{HO}$ after primary total hip arthroplasty in Indian population after using posterior approach with its incidence being higher in males as compared to the females.

\section{References}

1. Shehab D, Elgazzar AH, Collier BD. Heterotopic ossification. J Nucl Med. 2002; 43(3):346-53.

2. Freeman PA, Lee P, Bryson TW. Total hip joint replacement in Osteoarthrosis and polyarthritis. Clin Orthop 1973; (95):224-230.

3. Rosendahl S, Christoffersen JK, Norgaard M. Par articular ossification following hip replacement. Acta Orthop Scand. 1977; 48(4):400-404.

4. Riegler HF, Harris CM. Heterotopic bone formation after total hip arthroplasty. Clin Orthop. 1976; (117):209-216.

5. Nollen AJ, Slooff TJ. Para-articular ossification after 
total hip replacement. Acta Orthop Scand. 1973; 44(2):230-241.

6. Thomas BJ. Heterotopic bone formation after total hip arthroplasty. Orthop Clin North Am. 1992; 23(2):347358.

7. Ahrengart L. Periarticular heterotopic ossification after total hip arthroplasty. Risk factors and consequences. Cli Orthop Relat Res. 1991; 263(2):49-58.

8. Naraghi FF, De coster TA, Moneim MS, Miller RA, RIvero D. Heterotopic Ossification. Orthopedics. 1996; 19(2):145-151.

9. Nilsson OS, Persson P. Heterotpic bone formation after joint replacement. Curr opin Rheumatol. 1999; 11(2):127-3.

10. Ritter MA, Vaughan RB. Ectopic ossification after total hip arthroplasty: predisposing factors, frequency and effect on results. J Bone Joint Surg [Am]. 1977; 59(3):345-51.

11. J Coventry M, Robins PR. Heterotopic ossification: theoretical consideration possible etiological factors, and a clinical review of total hip arthroplasty patients exhibiting this phenomenon. In: The hip: procs 5th Open Scientific Meeting of the Hip Society. St Louis: CV Mosby. 1977, 201-21.

12. Zeckey C, Hildebrand F, Frink M, Krettek C. Heterotopic ossifications following implant surgery-epidemiology, therapeutical approaches and current concepts, Seminars in Immunopathology, 2011; 33(3)273-286.

13. Brooker AF, Bowerman JW, Robinson RA, Riley LH Jr. Ectopic ossification following total hip replacement. Incidence and a method of classification. J Bone Joint Surg Am 1973; 55(8):1629-32.

14. Chalmers J, Gray DII, Hush J. Observations on the induction of bone in soil tissues. J Bone Joint Surg. [Br]. 1975; 57(1):36-45.

15. Friedenstein AJ. Hard tissue growth. Repair and remineralization. New York, Associated Scientific, 1973, 169.

16. Puzas JE, Miller MD, Rosier RN. Pathologic bone formation. Clin Orthop. 1989; 245:269-281.

17. Urist MR. Bone formation by auto induction. Science 1965; 150(3698):893-9.

18. Urist MR. New bone formation induced in post fetal life by bone Morphogenic protein. In: Becker RO ed, Mechanisms of growth control. Springfield; Charics C Thomas. 1981, 406-434.

19. Ho SSW, Stern PJ, Bruno LP. Pharmacological inhibition of prostaglandin E2 in bone and its effect on pathological new bone formation in a rat burn model. Transac Orthop Res Soc. 1988; (13):536.

20. Tonna EA, Cronkite EP. Auto radiographic studies in cell proliferation in the periosteum of infact and fractured femora of mice utilizing DNA labeling with $\mathrm{H} 3$ thymidine. Proc. Soc. Exp. Biol Med. 1961; (107):719721.

21. Biz C, Pavan D, Frizziero A, Baban A, Iacobellis C. Heterotopic ossification following hip arthroplasty: a comparative radiographic study about its development with the use of three different kinds of implants. Journal of Orthopaedic Surgery and Research. 2015; 10(1):176.

22. Morrey BF, Adams RA, Cabanela ME. Comparison of heterotopic bone after anterolateral, trans trochanteric, and posterior approaches for total hip arthroplasty. Clin Orthop. 1984; (188):160-7.

23. Eggli S, Woo A. Risk factors for heterotopic ossification in total hip arthroplasty. Arch Orthop Trauma Surg. 2001; 121(9):531-5.

24. Fransen M, Neal B. Non-steroidal anti-inflammatory drugs for preventing heterotopic bone formation after hip arthroplasty. Cochrane Database Syst Rev. 2013; 28(3):CD001160. doi:10.1002/14651858.CD001160.pub3. 